\title{
Application of ultrasonic disintegration to waste activated sludge for increasing of biogas production by anaerobic digestion
}

httsp://doi.org/10.21698/rjeec.2020.202

Proceedings Paper

\author{
ION VIOREL PATROESCU ${ }^{1}$, RAZVAN LAURENTIU DINU ${ }^{1 *}$, MIHAI STEFANESCU ${ }^{1}$, \\ VALERIU ROBERT BADESCU ${ }^{1}$, NICOLAE IONUT CRISTEA ${ }^{1}$, COLINE MARTIN $^{2}$ \\ ${ }^{I}$ National Research and Development Institute for Industrial Ecology - ECOIND, 71-73 Drumul Podu Dambovitei,
O60652, Bucharest, Romania
${ }^{2}$ Universite Toulouse II-IUT “A” Paul Sabatier, 115 C Route de Narbonne, BP 67701-31077 Toulouse cedex 4, France
*corresponding author (e-mail): laurentiu.dinu@incdecoind.ro
}

Abstract

The municipal wastewater treatment is the source of significant amounts of primary and secondary sludge, which is under the present legislation referring to quality and management aspects. It is estimated that half of wastewater treatment plant costs are due to the sludge management. Anaerobically sludge stabilization, capitalization as an energy source, to diminish the costs and sludge volume decreasing, are the aims of the main operational steps of sludge treatment, as a part of wastewater treatment plant. The improvement of sludge anaerobically stabilization process must be possible by acting in the rate-limiting step - hydrolysis to rise the organic carbon solubilization. The increase of soluble carbon can be possible by adding a pretreatment step of waste biological sludge, ultrasonic disintegration being one option. This paper emphasized the experimental results regarding anaerobically stabilization of the thickened waste biological sludge by ultrasonication taking into account the results of the blank test, without ultrasonication. Experimental tests show that ultrasonic disintegration of the sludge having initial dried substances content (d.w) $2.72 \%$ and soluble organic load COD of $598 \mathrm{mg} \mathrm{O} / \mathrm{L}$ led to soluble COD concentration of 4950-6710 $\mathrm{mg} \mathrm{O}_{2} / \mathrm{L}$ after sonication with a specific energy in the range of $3.06-14.24 \mathrm{kWh} / \mathrm{kg} \mathrm{d.w.} \mathrm{Anaerobically}$ stabilization during 25 test days at $36^{\circ} \mathrm{C}$ of the mixture $40 \%$ disintegrated biological sludge and $60 \%$ digested sludge (inoculum) mixture led to $30-38.6 \%$ increase of biogas production comparing with parallel test with non-sonicated sludge.

Keywords: waste activated sludge, ultrasonic disintegration, anaerobically sludge digestion, biogas production

\section{INTRODUCTION}

Large amount of sludge is generated by municipal wastewater treatment plants (MWWTPs) as primary and waste activated sludge from primary and secondary sedimentation steps.

The MWWTP sludges have 95-99\% water content, the heterogeneous mixture having both solids in suspensions and colloidal system. The solids substances of these sludges are $65-75 \%$ organics being fermentable in aerobic or anaerobic conditions [1].

The treatment of MWWTP sludge must be done to diminish pathogens, strong odours, the volume/weight, to improve dewatering properties and to generate energy from biogas production, after anaerobically sludge digestion treatment phase $[2,3]$.

Anaerobically digestion with biogas generation is the best option in case of medium and big wastewater treatment plants. Anaerobically stabilization is the process of biodegradable organic matter transformation into $\mathrm{CH}_{4}$ (60$70 \%$ ) and $\mathrm{CO}_{2}$ [4]. Anaerobically fermentation consists of four main steps: hydrolysis and solubilization of organic matter, acidogenesis, acetogenesis (transformation of acidogenesis product into acetate) and methanogenesis (biogas generation from acetates, $65-75 \%$ of biogas production, and from $\mathrm{H}_{2}+\mathrm{CO}_{2}$ reaction) $[3,5]$.

The biogas production can be improved if the sludge is pre-treated before anaerobic digestion. The main pre-treatment methods of the sludge are as following $[6,7]$ :

- thermal: by heating the sludge to $90^{\circ} \mathrm{C}$ (approx. $1 \mathrm{~h}$ ) and cooling it after to the digestion selected temperature;

- chemical or electrochemical: Fenton oxidation leads to better nitrogen removal and higher biogas production as well as 
alkaline digestion [8];

- mechanical: improve the solubilization of organic matter and dewatering properties;

- ultrasonic: very efficient for organics solubilization because of mechanical (ultrasonic waves) and chemical oxidation effects (ultrasonic cavitation/sonolysis);

- hybrid methods: put together the advantages of above-mentioned methods (e.g. ultrasonics + Fenton oxidation).

Most of the sludge organic matter is insoluble and cannot be assimilated by specific microorganism in the anaerobic digestion step. Ultrasonication is one of the sludge pretreatment methods for organic load (COD or/and BOD indicators) solubilization with direct influence in biogas production increase

\section{EXPERIMENTAL PART}

The experimental tests were performed to establish the influence of ultrasonic energy to biogas production after anaerobic fermentation. There were two experimental stages: - ultrasonication of thickened waste activated sludge into ultrasonic reactor model SONICS Vibra Cell (Fig.1);
$[4,9]$.

Ultrasonic pre-treatment of the sludge can be done directly or after $\mathrm{pH}$ correction (alkaline ultrasonic method) $[3,10]$.

The main parameters of ultrasonic pretreatment process are sludge composition (solid substances content, COD and BOD of heterogeneous phase and dissolved phase, metals, ammonia etc), ultrasonic frequency, ultrasonic energy and amplitude, sonication time, ultrasonication equipment (tank with an ultrasonic source inside the walls, tank with multiple ultrasonic probes) $\mathrm{pH}$ and temperature control system $[1,4]$.

The following experimental will demonstrate the effect of sludge ultrasonic disintegration to anaerobically digestion efficiency.

- anaerobically digestion of three ultrasonicated sludge samples and one blank sample (nonultrasonicated) using a battery tests equipment model Puls Flow Respirometer PF 8000 placed inside the incubator - shaker (Brunswick Scientific - Innova 44, Fig. 2).

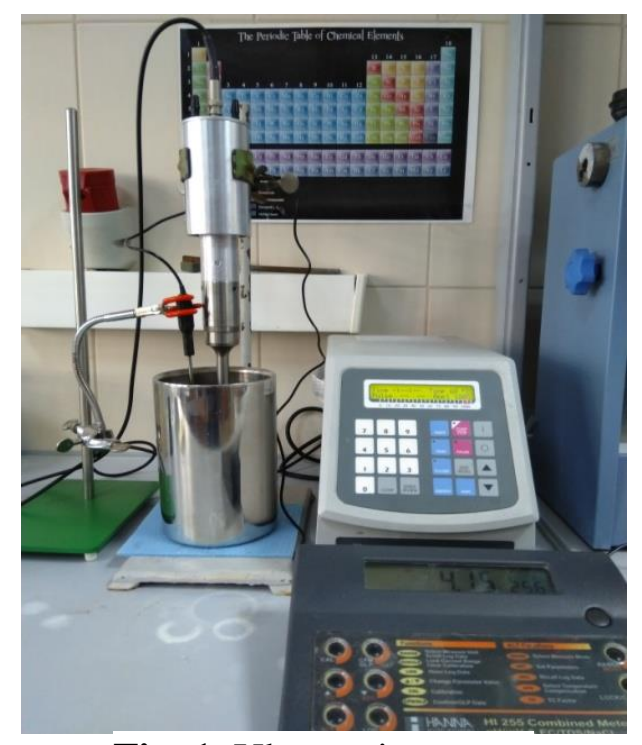

Fig. 1. Ultrasonic reactor

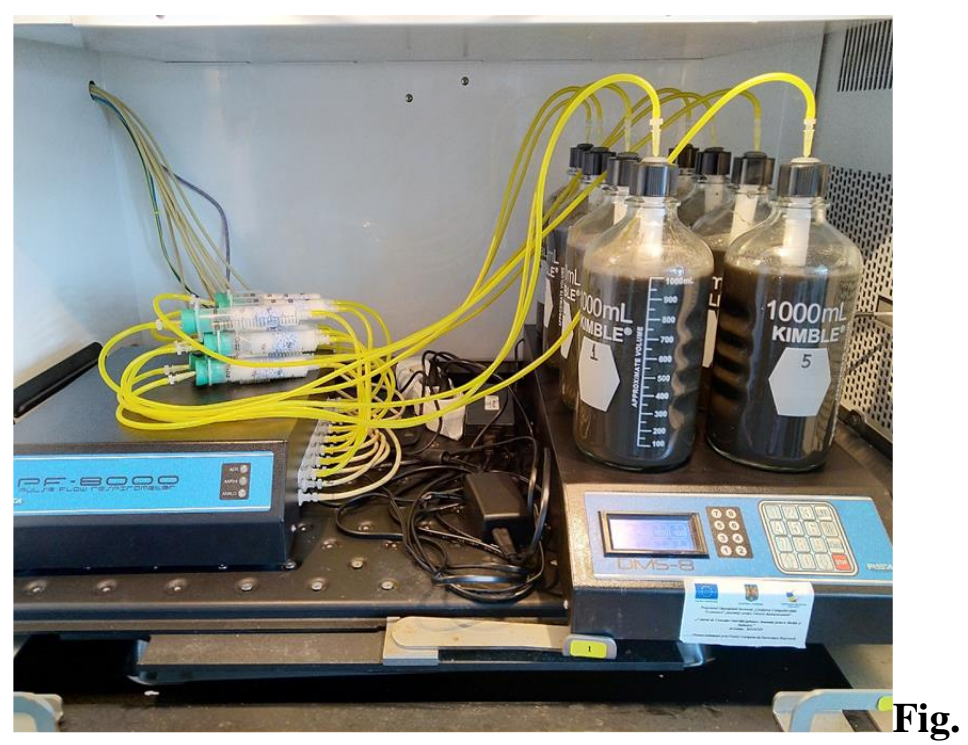

2. Anaerobically digestion battery tests
The main operational conditions for ultrasonic pretreatment were as following:

- sludge samples were mixtures of thickened waste activated sludge (BS) and fermented sludge (FS noculum):

- BS: COD homogeneous $=29040 \mathrm{mg} \mathrm{O} / \mathrm{L}$,

$\mathrm{COD}_{\text {dissolved }}=598 \mathrm{mg} \mathrm{O}_{2} / \mathrm{L}$, dried substances (d.w.) content $=2.72 \%$, volatile substances content $=72.3 \%$

- FS: $\mathrm{COD}_{\text {homogeneous }}=22000 \mathrm{mg} \mathrm{O} / \mathrm{L}$, $\mathrm{COD}_{\text {dissolved }}=554 \mathrm{mg} \mathrm{O}_{2} / \mathrm{L}$, dried substances (d.w.) content $=2.13 \%$, volatile substances content $=61.3 \%$

- ultrasonic frequency was constant for all 
samples: $20 \mathrm{kHz}$;

- ultrasonic amplitude was constant for all samples: $100 \%$;

- specific ultrasonic energy applied:

$3.06 \div 14.24 \mathrm{kWh} / \mathrm{kg}$ d.w.;

Anaerobically fermentation was performed to $36^{0} \mathrm{C}$ with continuous shaking ( $\left.800 \mathrm{rpm}\right)$ during 25 days and the operational parameters are presented below:

- bioreactor M (1 L) - blank test: 0.4 L BS (non-ultrasonicated) $+0.6 \mathrm{~L}$ of FS,
- bioreactor B1 (1 L) - test: 0.4 L BS after ultrasonication to $11016 \mathrm{~kJ} / \mathrm{kg}$ d.w. (3.06 $\mathrm{kWh} / \mathrm{kg} \mathrm{d.w.)} \mathrm{+} \mathrm{0.6} \mathrm{L} \mathrm{of} \mathrm{FS,}$

- bioreactor B2 (1 L) - test: 0.4 L BS after ultrasonication to $22032 \mathrm{~kJ} / \mathrm{kg}$ d.w. (7.12 $\mathrm{kWh} / \mathrm{kg}$ d.w.) $+0.6 \mathrm{~L}$ of FS,

- bioreactor B3 (1 L) - test: 0.4 L BS after ultrasonication to $44024 \mathrm{~kJ} / / \mathrm{kg}$ d.w. (14.24 $\mathrm{kWh} / \mathrm{kg}$ d.w.) + 0.6 L of FS.

\section{RESULTS AND DISCUSSION}

The influence of ultrasonic energy to organic investigated.

load solubilization and biogas production was

The influence of ultrasonic energy on dissolved COD

The ultrasonic effect to COD solubilization and volatile substances of biological sludge (BS) consists of a significant increase of $\mathrm{COD}_{\text {dissolved }}$ along with decreasing of volatile substances (v.s.) content (Table 1).

The organic load (COD) in soluble form

increase constantly with ultrasonic energy doubling being $6700 \mathrm{mg} \mathrm{O} / \mathrm{L}$ in case of US3 sample (over 11 times higher with initial BS). The decrease of dried and volatile substances content was about 9 and $8 \%$, respectively.

Table 1. The influence of ultrasonic energy on dissolved organic load ( $\left.\mathrm{COD}_{\text {dissolved }}\right)$, dried and volatile substances content in ultrasonication stage

\begin{tabular}{c|ccccc}
\hline Sample & $\begin{array}{c}\text { Specific US energy } \\
(\mathrm{kWh} / \mathrm{kg} \mathrm{d.w.})\end{array}$ & $\begin{array}{c}\mathrm{COD}_{\text {homogeneous }} \\
\left(\mathrm{mg} \mathrm{O}_{2} / \mathrm{L}\right)\end{array}$ & $\begin{array}{c}\mathrm{COD}_{\text {dissolved }} \\
\left(\mathrm{mg} \mathrm{O}_{2} / \mathrm{L}\right)\end{array}$ & $\begin{array}{c}\text { d.w. } \\
(\%)\end{array}$ & $\begin{array}{c}\text { v.s. } \\
(\% \text { x d.w. })\end{array}$ \\
\hline BS & 0 & 29040 & 598 & 2.72 & 72.33 \\
US1 & 3.06 & 22900 & 4950 & 2.56 & 67.30 \\
US2 & 7.12 & 21950 & 6040 & 2.53 & 66.70 \\
US3 & 14.24 & 19800 & 6710 & 2.48 & 66.47 \\
\hline
\end{tabular}

The influence of ultrasonic energy on biogas production

Ultrasonic pretreatment of biological sludge acts to hydrolysis step to dissolve solid organic matter. The specific microorganism can eat organic matter only in dissolved phase so, ultrasonic pretreatment increases the access to a concentrated "soup" leading to a more performant anaerobically digestion and in consequence, a higher volume of biogas.

Table 2 shows the organic load, dried and volatile substances levels before and after anaerobically digestion of ultrasonicated sludge mixture (40\% ultrasonicated biological sludge +
$60 \%$ inoculum) - bioreactors B1, B2, B3, and one non-sonicated sample of $\mathrm{M}$ bioreactor.

The dissolved organic load decrease after anaerobic digestion for each bioreactor having pretreated biological sludge (B1-B3) because of transformation into biogas. This transformation involved $10.5-28.5 \%$ of dissolved matter as COD soluble. The same evolution was for dried and volatile substances concentrations, where the decrease were about 12 and $11 \%$, respectively. 
Table 2. The influence of ultrasonic energy on dissolved organic load ( $\left.\mathrm{COD}_{\text {dissolved }}\right)$, dried and volatile substances content in anaerobically digestion stage

\begin{tabular}{c|ccccccc}
\hline Bioreactor & $\begin{array}{c}\text { Specific US } \\
\text { energy } \\
\text { (kWh/kg d.w. })\end{array}$ & $\begin{array}{c}\text { Initial } \\
\mathrm{COD}_{\text {dissolved }} \\
\left(\mathrm{mg} \mathrm{O}_{2} / \mathrm{L}\right)\end{array}$ & $\begin{array}{c}\text { Final } \\
\mathrm{COD}_{\text {dissolved }} \\
\left(\mathrm{mg} \mathrm{O}_{2} / \mathrm{L}\right)\end{array}$ & $\begin{array}{c}\text { Initial } \\
\text { d.w. } \\
(\%)\end{array}$ & $\begin{array}{c}\text { Final } \\
\text { d.w. } \\
(\%)\end{array}$ & $\begin{array}{c}\text { Initial v.s. } \\
(\% \text { x d.w. })\end{array}$ & $\begin{array}{c}\text { Final } \\
\text { v.s. } \\
(\% \text { x d.w. })\end{array}$ \\
\hline $\mathrm{M}$ & 0 & 570 & 1496 & 2.35 & 2.01 & 64.48 & 57.80 \\
$\mathrm{~B} 1$ & 3.06 & 2310 & 2068 & 2.30 & 2.01 & 63.71 & 56.85 \\
$\mathrm{~B} 2$ & 7.12 & 2750 & 2156 & 2.29 & 2.01 & 63.48 & 56.70 \\
$\mathrm{~B} 3$ & 14.24 & 3014 & 2156 & 2.27 & 1.99 & 63.38 & 56.35 \\
\hline
\end{tabular}

Table 3 and Figure 3 emphasized the increase of biogas production and decrease of volatile substances amount after anaerobic digestion.

Table 3. The influence of ultrasonic energy on dissolved organic load ( $\left.\mathrm{COD}_{\text {dissolved }}\right)$ and volatile substances amount in anaerobically digestion stage

\begin{tabular}{c|cccc}
\hline Sample & $\begin{array}{c}\text { Volatile substances } \\
\text { diminishing } \\
(\%)\end{array}$ & $\begin{array}{c}\text { Biogas } \\
\text { production } \\
(\mathrm{mL})\end{array}$ & $\begin{array}{c}\text { Specific biogas } \\
\text { production, } \mathrm{m}^{3} / \mathrm{kg} \text { v.s. } \\
\text { diminishing }\end{array}$ & $\begin{array}{c}\text { Increase of biogas } \\
\text { production toward } \\
\text { M bioreactor }(\%)\end{array}$ \\
\hline M & 23.33 & 3326 & 1.045 & 0 \\
B1 & 22.02 & 3946 & 1.359 & 30.04 \\
B2 & 21.60 & 3958 & 1.400 & 33.97 \\
B3 & 22.06 & 4136 & 1.448 & 38.56 \\
\hline
\end{tabular}

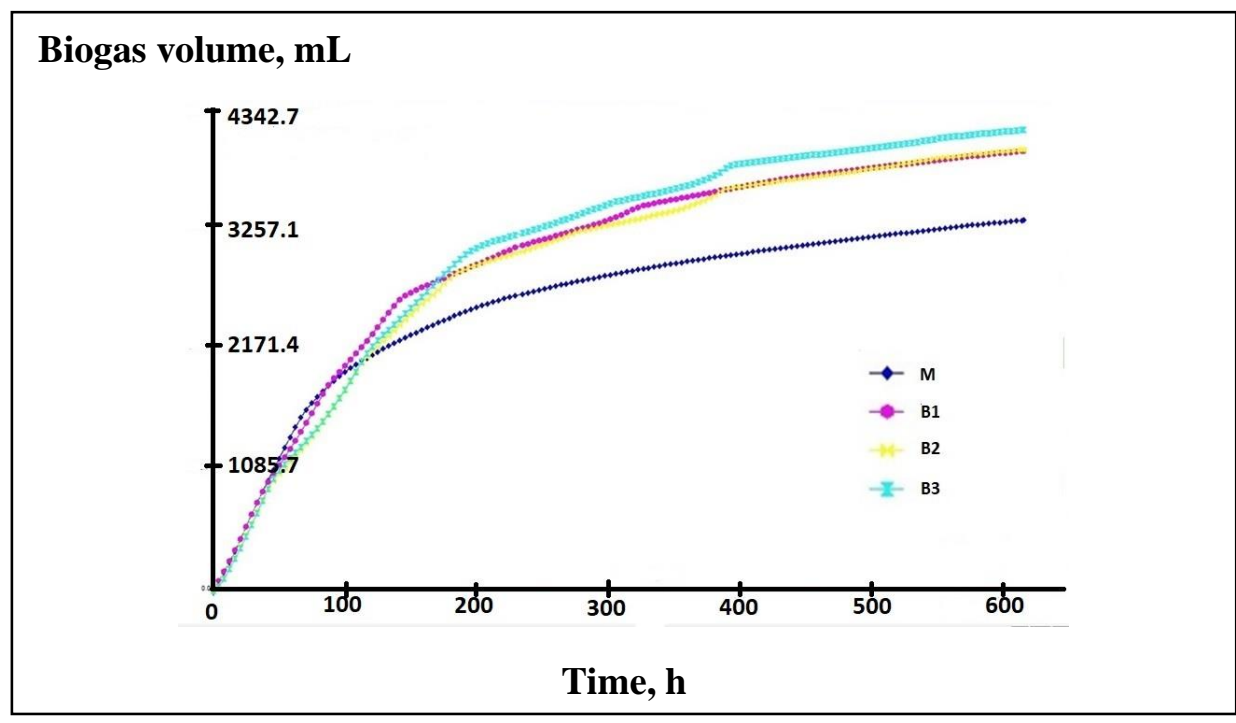

Fig. 3. The evolution of biogas production during 25 days of anaerobic fermentation

The analyses of experimental data highlighted the following:

- the amount of the volatile substance decreases with $22-23 \%$, for all bioreactors,

- the biogas production (from $1 \mathrm{~L}$ initial sludge mixture) was higher than $M$ reactor for all the bioreactors having initial ultrasonic pretreated sludge content (40\%); bioreactor B3 produced $24 \%$ more biogas (4 $136 \mathrm{~mL})$ than $\mathrm{M}$ reactor $(3326 \mathrm{~mL})$,
- specific biogas production for B1-B3 test reactors was in the range of 1.36-1.45 $\mathrm{m}^{3} / \mathrm{kg}$ comparing with 1.04 in case of blank reactor $\mathrm{M}$,

- the increase of biogas production for B1-B3 referring to $\mathrm{M}$ was $30 \%$ for $\mathrm{B} 1$ - the lower specific ultrasonic energy $(3.06 \mathrm{kWh} / \mathrm{kg}$ d.w.) and $38 \%$ for B3 - the highest specific ultrasonic energy (14.24 kWh/kg d.w.). 


\section{CONCLUSIONS}

Experimental tests were performed to quantify the influence of ultrasonic pretreatment of waste activated sludge to the efficiency of the following sludge treatment step - anaerobically digestion. Three main parameters have been chosen to describe the experimental results: organic load as chemical oxygen demand (COD) indicator (especially in soluble phase), dried and volatile substances content (d.w. and v.s.) and the biogas volume generated during 25 days of anaerobic digestion.

These process indicators were feasible instruments to describe both ultrasonic pretreatment stage (ultrasonication with three different specific US energies $(3.06 \div 14.24$ $\mathrm{kWh} / \mathrm{kg} \mathrm{d.w.)} \mathrm{and} \mathrm{anaerobically} \mathrm{digestion} \mathrm{steps.}$

\section{ACKNOWLEDGEMENTS}

Operational Programme Competitiveness 20142020, Contract no. 55/05.09.2016, Project ID-

\section{REFERENCES}

[1] BRISOLARA, K.F., Y. Qi, Water Environ Res, 83, no. 10, 2011, p. 1351-1375.

[2] APPELS, L., BAEYENS, DEGREVE, J., DEWIL, R., J. Prog Energ Combust Science, 34, no. 6 ,

2008, p. 755-781.

[3] LU, D., XIAO, K., CHEN, Y., SOH, Y.N., ZHOU, Y., Water Res, 142, 2018, p. 138-146.

[4] KAZMIERCZAK, M., Land Reclam, 44, no. 2, 2012, p. 101-107

[5] XU, X., CAO, D., WANG, Z., LIU, J., GAO, J., SANCHUAN, M., Ultrason Sonochem, 57, 2019, p. 29-37.

[6] CESARO, A., VELTEN, S., BELGIORNO,
The biogas production was $30 \%$ higher in case of bioreactor having biological sludge with lower applied specific ultrasonication energy $3.06 \mathrm{kWh} / \mathrm{kg}$ d.w. comparing with blank bioreactor (no ultrasonication before fermentation). $38 \%$ higher was the biogas production for the highest ultrasonic energy (14.24 kWh/kg d.w.) but can be considered that $8 \%$ more biogas doesn't justify this higher energy consumption.

These preliminary tests prove that ultrasonic disintegration appears as a promising waste activated sludge pretreatment method for biogas production increase by anaerobic digestion, but a cost-benefit analysis is necessary to prove its feasibility.

40-300, SMIS 105581, Subsidiary contract no. $6538 / 27.04 .2018$ supported this research.

V., KUCHTA, K., J Clean Prod, 74, 2014, p. 119-124.

[7] CHISTI, Y., Trends Biotechnol, 21, no. 2, 2003 p. 89-93.

[8] KAVITHA, S., BANU, J.R., SHAJU, C.D., KALIAPPAN, S., YEOM, I.T., Bioresour Technol, 221, 2016, p. 1-8.

[9] CARRÈRE, H., DUMAS, C., BATTIMELLI, A., BATSTONE, D.J., DELGENES, J.P., STEYER, J.P., FERRER, I., J Hazard Mater, 183, no. 1-3, 2010 p. 1-15.

[10] KIM, D.H., JEONG, E., OH, S.E., SHIN, H.S., Water Res, 44, no. 10, 2010, p. 3093-3100 